The impact of regulatory quality and corruption on residential electricity prices in the context of electricity market reforms

Peer-reviewed author version

KALLER, Alexander; BIELEN, Samantha \& MARNEFFE, Wim (2018) The impact of regulatory quality and corruption on residential electricity prices in the context of electricity market reforms. In: Energy policy, 123, p. 514-524.

DOI: 10.1016/j.enpol.2018.09.008

Handle: http://hdl.handle.net/1942/27144 


\title{
The Impact of Regulatory Quality and Corruption on Residential Electricity Prices in the Context of Electricity Market Reforms
}

\author{
Alexander Kaller ${ }^{*}$, Samantha Bielen*, Wim Marneffe ${ }^{* *}$
}

\begin{abstract}
The European electricity markets have been undergoing significant regulatory reforms since the introduction of the first liberalisation directive in 1996. Theory predicts that liberalisation promotes cost-efficient production and competition and hence leads to lower prices. The goal of this paper is to assess the impact of regulatory quality and non-compliance with the law on electricity prices in the context of electricity market reforms. We address problems of endogeneity by using the Blundell-Blond System GMM estimator and find that vertical integration and market concentration lower end-user prices, all else equal. Moreover, improving regulatory quality and reducing corruption, both have a negative impact on prices when holding other factors constant. The intensity of the reforms has limited impact on electricity prices when these reforms are introduced in an institutional environment characterised by high levels of corruption and low quality regulation.
\end{abstract}

Keywords: Liberalisation; Electricity prices; Regulatory quality; Market Reforms; Corruption

\footnotetext{
${ }^{*}$ Hasselt University, Faculty of Business Economics, Hasselt, Belgium

** Corresponding author. Hasselt University, Faculty of Business Economics, Hasselt, Belgium. E-mail address: wim.marneffe@uhasselt.be (W. Marneffe)
} 


\section{Introduction}

Two decades have passed since the first major European-wide electricity market reforms were introduced in 1996. Following the reforms in the late eighties in Great Britain with the introduction of the Electricity Act in 1989, the reform process earned an important place on the policy agenda of the European Commission. The main goal of the European market reforms was and still is the creation of a competitive internal market with free choice for consumers so they can benefit from lower prices and efficient services. Moreover, the reforms aimed at stimulating an environmentally friendly energy production and to ensuring greater security of supply.

A vast amount of research has been pursued in the field of market reforms of the electricity sector pointing out its flaws, successes and difficulties. Based on the literature, the outcomes of these reforms are highly uncertain. Economic theory predicts that deregulation ${ }^{1}$, or in this case liberalisation, would promote cost-efficient production, leading to lower prices. Furthermore, this would also lead to more choice, attract foreign investments and increase the quality and quantity of services enjoyed by the consumers. The goal of this paper is twofold. First, we will provide a literature review of research on the drivers of end-user electricity prices in the context of electricity market reforms. Second, we want to assess the impact of institutional variables, more specifically of regulatory quality and corruption, on residential electricity prices in the context of these reforms. Since the restructured

\footnotetext{
${ }^{1}$ Deregulation might be a somewhat misleading term since old regulation is being replaced by new regulation. The deregulation movement always involves some form of re-regulation.
} 
electricity market is subject to different market forces, regulation and the functioning of the institutions responsible for enforcing these regulations play an increasingly important role in protecting different consumer groups and ensuring that the benefits of market reforms are passed on to consumers. We believe that the institutional design of the reforms and the compliance with the rules stemming from them, play an important role in reducing electricity prices for end-users. To the best of our knowledge, an analysis of institutional factors within the context of electricity market reforms and their impact on prices, has not been performed before.

This paper is structured as follows. Section 2 provides a summary of the European legal framework concerning electricity market reforms. The third section consists of a literature review of the existing literature on the drivers of end-user electricity prices. Section 4 takes a closer look at the dataset, the regression models used in our analysis and the results. Finally, the last section contains concluding remarks and policy recommendations along with some suggestions for further research.

\section{Electricity market reforms in the European Union}

The electricity market reforms were initiated with the first liberalisation directive 96/92/EC, which laid down a regulatory framework for the internal electricity market in the European Union. One of the main objectives of this directive was the partial and gradual opening of the electricity markets in the Member States. Furthermore, when organising the access to their transmission and distribution networks, the Member States had the choice to either opt for a regulated or negotiated third party access (TPA) or for a single buyer model. The first directive was then repealed by 
directive 2003/54/EC 2 . The main goals of this directive were; the creation of an independent regulatory agency by each Member State, the appointment of transmission and distribution system operators, and their legal unbundling with the separation of the internal accounts of electricity companies for each of their transmission and distribution activities. Furthermore, the directive introduced a fair TPA to the grid, further strengthened the protection of the end-users and allowed electricity consumers to freely choose their supplier. Growing concerns and complaints expressed by end-users and new entrants in the sector led the European Commission to launch an inquiry in 2005 to investigate the functioning of the electricity and gas market. The final report of this sector inquiry was published in January 2007 and pointed out some serious obstacles (e.g. high market concentration, vertical foreclosure, limited market integration, lack of transparency, non-effective and non-transparent price formation, limited retail competition and malfunctioning balancing markets) which stood in the way of pursuing the goals of the liberalisation policy (European Commission, 2007). Next to enforcing competition rules through courts, this report also led to the introduction of the third liberalisation directive. Directive 2009/72/EC repealed directive 2003/54/EC and had to be implemented by the Member States by March 2011. It required the electricity companies to either opt for a full separation of their transmission assets from their generation and supply activities or for retaining their assets but letting them being managed by an independent system operator appointed by the government of the Member State. Furthermore, Member States were allowed to opt for a legal separation with the transmission activities being managed by an independent transmission operator.

\footnotetext{
${ }^{2}$ This directive had to be transposed into national regulation by July 2004 , except for Article 15 , which had to be transposed by July 2007.
} 
Additionally, the independence and the authority of the national regulatory agencies were strengthened, a new European agency ${ }^{3}$ was created and the end-user rights were improved.

\section{Literature on the impact of electricity market reforms on electricity prices}

In the following section, we will provide a review of the literature on the impact of regulatory reforms in the electricity sector on end-user electricity prices. Studies regarding wholesale electricity prices have been omitted. ${ }^{4}$ Consequently, end-users who are supplied directly by generators (e.g. medium to large industrial customers) have also been excluded from this review if they have been analysed as a separate group by the authors. Papers with a specific focus on electricity generation from renewable sources in the EU have been included since renewables have been explicitly mentioned on multiple occasions in the liberalisation directives as one of the instruments in achieving a well-functioning liberalised electricity market.

The search process was conducted in 2017. We performed an extensive search for relevant research material (including working papers, conference papers, and reports) starting from $1995^{5}$ on EBSCOhost, Google Scholar, Science direct and Web of Science with Hasselt University authentication. We used a combination of the following keywords in the research process: electricity price, electricity rate, market reforms, liberalisation, deregulation, impact, effect, drivers, industrial, residential.

\footnotetext{
${ }^{3}$ Agency for Cooperation of Energy Regulators.

${ }^{4}$ Retail electricity prices are influenced differently if compared to wholesale prices. A drop in wholesale prices does not automatically imply that retail prices will drop as well.

${ }^{5}$ This date has been chosen because electricity market reforms in Europe would only start showing an effect after a few years into the reforms.
} 
Furthermore, we analysed all references in relevant studies in order to verify that we captured most of the literature on this topic. Nevertheless, it is still possible that the literature list presented in this paper is non-exhaustive. ${ }^{6}$ Even though the focus of our paper is on electricity market reforms in Europe, literature on non-European countries has also been taken into account in order to capture all relevant variables within the context of reforms. A first screening of the papers was performed based on the abstract and the conclusions. This allowed us to exclude studies, which were not relevant to our analysis. This procedure resulted in 38 papers, which we clustered in four major categories based on the method used: regression analyses (15), descriptive analyses (11), simulations ${ }^{7}$ (6) and reviews/discussions (6).

The majority of the studies focused on Europe or European countries (22). Six papers investigated electricity market reforms in multiple countries throughout different continents while the rest of the studies (8) focused on specific countries or regions worldwide (excluding European countries). Two of the remaining studies did not mention specific countries but rather looked at the available evidence of electricity market reforms to date. A graphic overview of the papers per region and research method is displayed in Fig 1.

Fig 1. Number of papers per region and per research method Fig 1. here

${ }^{6}$ We did not have access to all available papers, especially those published before the year 2000.

${ }^{7}$ Using simulation models to predict future price movements. 
A more detailed overview of the reviewed articles by author, methods used, time interval and region is presented in table 1.

Table 1 Literature overview

\section{Table 1 here}

Each paper was analysed in order to extract relevant variables, which could influence end-user electricity prices. This overall process resulted in 81 unique variables. We then excluded all variables not related to papers that used regression analyses, which will allow us to select suitable variables for our econometric models later on. It is possible that variables can be partly overlapping. However, the variables included in the table are distinct in the sense that they may relate to each other in general (e.g. market reforms) but they differ based on the underlying data and the specific topic they try to measure. For example, "time to privatisation" measures the expected amount of years remaining until the electricity sector is privatised while "privatisation" either uses a dummy or a scale in order to indicate if they electric sector is privatised and to what extent. The goal of this analysis was to examine whether the underlying data of the variables was the same but just labelled differently. In the latter case, we grouped the variables together and assigned the same label. The most used 20 variables together with their influence on electricity prices are presented in table 2 . The second column shows the number of occurrences of a specific variable in the reviewed papers. The last three columns indicate whether the variable had a positive, negative, or no significant influence on electricity prices. Some variables can have both a positive and negative impact on electricity prices in a given paper or no impact at all. This difference in results can be ascribed to the 
different models utilised or if the author(s) analysed data across different regions/countries. For example, Nagayama (2009) finds that market reforms had a negative influence on prices in Asian developing countries whereas prices increased after market reforms in developed countries. Therefore, the sum of these three columns is always equal or higher than the number specified in the "Count" column.

Table 2 Most used 20 variables

Table 2 here

Around one fifth of the analysed papers used a variable for hydro generation to investigate its influence on electricity prices. Scholars mostly find that hydro generation has no significant impact on prices or leads to a decline of prices for endusers.

A country's or region's economic growth ${ }^{8}$ was found to have a positive or no significant impact on electricity prices. An increase in economic activity leads to a rise in electricity demand, which in turn has a positive influence on electricity prices if the rise in electricity demand is combined with generation capacity or interconnection constraints.

Generating electricity from nuclear power plants as well as the unbundling of generation and transmission activities within the electricity sector has no significant impact on prices in the majority of the reviewed papers.

The presence of a wholesale market and the introduction of retail competition mainly has a negative impact on electricity prices. However, a negative impact on end-user prices can only be achieved if there is a strong link between the wholesale and retail

${ }^{8}$ Measured by GDP or GDP per capita. 
level. The estimated time to liberalisation and privatisation, respectively have a positive or no significant impact on prices.

Two papers used a variable for market reforms and the influence on electricity prices was mainly statistically insignificant or negative.

The generation of electricity from combustible fuels has a positive or no significant impact on prices. Furthermore, interconnection can either have a positive or negative impact on prices.

The presence of market power and private ownership can have a positive or negative impact on prices or no significant impact at all. Generating electricity from fossil fuels leads to higher prices.

Finally, electricity imports, electricity sales, residential consumption, public ownership and the presence of entry regulation are mainly associated with lower electricity prices.

Furthermore, we clustered the selection of 81 variables into four different categories based on their characteristics: market reforms (including variables related to the structure and functioning of the electricity markets), renewable energies (including renewable policies), electricity generation (excluding renewables) and country/region specific variables (variables not directly related to the electricity markets such as GDP, Heating Degree Days, level of democracy, ... $)^{9}$.

A schematic presentation of the papers based on their respective variable category is displayed in Fig 2. Six out of 38 papers utilise variables which could be assigned to

${ }^{9}$ These variables are mostly used as control variables as they are not directly related to regulatory reforms. 
all four categories. Four papers use variables for market reforms in conjunction with those for either electricity generation or renewable energies. Three papers use both country specific and market reforms variables as well as variables for either renewable energies or electricity generation. The majority of the reviewed papers (19) focus mainly on market reforms with two of them also including country specific variables in their analysis. The impact on end-user prices only using variables for renewable energies is analysed in 7 out of 38 papers.

Fig 2. Papers and their variable categories

Fig 2. here

In the following paragraphs, we will provide an in-depth review of the selected papers based on the four categories presented in Fig 2. (market reforms, electricity generation, renewables energies and country/region specific variables).

\subsection{Market reforms}

\section{General}

Several authors have described the ex-ante and ex-post impact of regulatory reforms on electricity prices. Amundsen et al. (1998) evaluated the impact of deregulation and free trade in the Nordic countries on electricity prices. They find that free trade leads to the convergence of prices among countries, which is beneficial for consumers in countries with initially higher prices and vice versa. A counterfactual price analysis has been performed by Branston (2000). He concludes that 
privatisation has led to a significant increase in electricity prices. However, it is not unlikely that the privatised electricity sector would provide cheaper electricity in the long run. Joskow (2008) provides an historical overview on the lessons learned from electricity market reforms. He states that that liberalisation will not always lead to a decrease in electricity prices for consumers. In countries where regulated prices were inefficiently low, discouraging investments and promoting wasteful overconsumption, liberalisation is likely to lead to higher prices. Such a situation occurred in Hungary where higher electricity prices were necessary to attract foreign investors (Bakos, 2001). The influence of strategic consolidation among electricity producers on German end-user electricity prices was investigated by Bower et al. (2001). They find that mergers lead to higher electricity prices, well above competitive levels. Moreover, Domanico (2007) analysed market power exercised by electricity producers. Producers can increase prices by either withdrawing capacity or by utilising more expensive inframarginal plants. Nagayama (2009) found that higher prices seem to be one of the driving forces for adopting certain liberalisation models, after analysing the impact of electricity prices on the selected liberalisation models and subsequently the impact of the chosen liberalisation model on industrial and residential electricity prices. While electricity market reforms actually lowered electricity prices for industrial users in Asian developing countries, prices for industrial and residential users in developed countries had a tendency to rise. Woo and Zarnikau (2009) find that it is unlikely that electricity market reforms will result in lower electricity prices. Analysing the growing energy poverty in Australia, Chester and Morris (2012) find comparative evidence of rising electricity prices for households since the market reforms have started worldwide. After reviewing the existing literature on the impact of liberalisation on efficiency, investments, services 
and prices, Pollitt (2012) concludes that liberalisation can lead to higher prices for some consumers. Karahan and Toptas (2013) studied the impact of privatising the electricity distribution companies in Turkey and find that privatisation has not lead to the expected price declines. Even though wholesale electricity prices have decreased in real terms, this reduction is not reflected on end-user prices because distribution companies tend to charge higher costs for the distribution activities after privatisation. In Spain, market reforms led to higher end-user prices due to the increase in adjustment service costs at the distribution level (Batalla-Bejerano et al., 2016). Hooks and Tooley (2015) found that deregulation and privatisation have led to an increase in end-user electricity prices in Queensland and New Zealand. According to them, this increase can be attributed to the public ownership of certain electricity sector activities in both regions.

Domah and Pollitt (2001) evaluate the gains and losses from restructuring and privatisation of the regulated supply and distribution businesses of the regional electricity companies in England and Wales. They find that residential users benefit from slightly lower prices but only starting from the year 2000. Doove et al. (2001) utilises a benchmark approach to reassess the findings by Steiner (2001) while extending the sample to 50 economies. They find that unbundling generating and transmission activities, allowing TPA and introducing a wholesale electricity market, all lead to lower electricity prices for end-users. The results for private ownership and the imminence of liberalisation and privatisation are more ambiguous since these indicators have several limitations, casting doubt about the robustness and policy relevance of the resulting findings. De Oliveira and Tolmasquim (2004) provide a survey of the electricity market reforms in the UK for the period 1989-2000 which 
led to lower prices for industrial and residential users. However, the authors express doubts about the real advantages and sustainability of these price benefits from the point of view of the residential consumers. Finally, Akkemik and Oğuz (2011) examine the impacts of full liberalisation on the Turkish electricity sector and conclude that liberalisation will reduce electricity prices for households.

\section{Country specific variables}

A game theoretic model was used by Lise et al. (2008) to study the impact of dry weather and more transmission capacity on electricity prices. They conclude that under perfect competition, international price differences are due to the limited interconnection capacity and the presence of various generation technologies. Dry weather is associated with higher electricity prices in hydro-rich countries due to reduced availability of hydroelectric power generation, especially in the presence of market power. Furthermore, they find a correlation between market power and high electricity prices in countries with a limited number of firms. Sen and Jamasb (2012) perform an econometric analysis on the determinants and the impact of electricity market reforms on prices in 19 Indian states, over the period 1991-2007. Their findings suggest that the presence of an energy regulatory agency and GDP per capita ${ }^{10}$ have a positive influence on industrial electricity prices. The passing of tariff orders and the introduction of open access to the electricity grid lead to lower prices.

\section{Renewable energies}

\footnotetext{
${ }^{10}$ Used as a proxy to indicate the wealth level in a region.
} 
After analysing the impact of tradable green certificates quotas in Nordic countries, Unger and Ahlgren (2005) conclude that higher quotas lead to lower wholesale electricity prices. The result for consumer prices might be positive or negative depending on the volume of the applied quotas. The impact of renewable electricity support systems on German electricity prices was investigated by Bode (2006) and Rathmann (2007). Bode finds that the net effect of using support schemes for renewable energy sources for electricity (RES-E) on consumer electricity prices may be positive or negative, depending on the characteristics of the electricity market and the value imputed to the power generated by renewable sources. Rathmann (2007), on the other hand, concludes that support systems for RES-E have reduced the wholesale electricity prices and, consequently, prices for consumers. A study on the impact of market reforms and renewable energies on prices in 27 European Union countries was done by Moreno et al. (2012) ${ }^{11}$. They find that household electricity prices increase if more electricity is generated from renewable sources and if more greenhouse gas emissions are produced since the latter is directly related to emission trading schemes. Moreover, market concentration in electricity generation is associated with lower prices for residential users. Costa-Campi and Trujillo-Baute (2015) found that electricity generation from renewable sources exert a downward pressure on wholesale electricity prices in Spain. However, this effect is offset by the feed-in-tariff leading to an increase in retail electricity prices. Using a simulation model, Osorio and van Ackere (2016) found that the impact of the nuclear phase-out and the replacement of nuclear power generation by variable renewable energies in Switzerland, will eventually lead to higher end-user prices for electricity.

\footnotetext{
${ }^{11}$ This paper is the only paper that utilises variables from the categories "market reforms" and "renewables energies". Therefore, we decided to include it in this subsection instead of creating a new one.
} 
de Miera et al. (2008) found that the reduction in electricity prices in Spain due to renewable energy generation is larger than the increase in costs associated with support schemes. Consequently, this leads to lower prices for consumers. Finally, according to Munksgaard and Morthorst (2008), wind power generation in Denmark as such leads to a decline in electricity prices paid by consumers. However, due to the subsidy, which is paid by electricity consumers to the wind power producers, the prices are higher compared to a scenario without wind power generation. In cases when a certain area is separated from the rest of the market, prices are lower compared to the rest of the market.

\subsection{Market reforms and electricity generation}

\section{General}

An empirical analysis on the impact of the electricity market reforms on prices was performed by Martin and Vansteenkiste (2001). A reduction in public ownership has a significant negative impact on electricity prices. The introduction of competition does lead to a reduction in prices for industrial users. Moreover, prices for residential users are more influenced by natural gas prices and the share of natural gas in electricity generation. Thus, moving to more environmentally friendly and modern generation technologies has a downward impact on electricity prices. Percebois (2008) concludes that the liberalisation of the electricity sector in Europe has not led to the promised price decreases for consumers. It is not as much the liberalisation process that is directly responsible for price increases, but rather the development of interconnection capacity, which leads to the convergence of electricity prices among 
countries. Moreover, the increasing prices could partially be accounted to the growing concentration of electricity companies in Europe creating possibilities for power abuse. Furthermore, most reforms were implemented at a time when fossil fuel prices were low, creating a false perception that prices will remain low in the future. Panel data analysis of the impact of regional transmission organisations and independent system operators on electricity prices in the United States did not yield significant results (Kury, 2013).

\section{Country specific variables}

Fiorio and Florio $(2009,2013)$ studied the impact of the reforms in EU15 countries and come to the conclusion that the prices for electricity are on average lower in countries with public ownership. Entry legislation is associated with lower prices for consumers while vertical integration has no significant impact on electricity prices. Furthermore, countries where at least $10 \%$ of produced electricity comes from nuclear power sources, experience lower end-user prices. Finally, GDP per capita has a positive influence on electricity prices.

\subsection{Market reforms, electricity generation and renewable energies}

Steiner (2001) uses a panel regression to assess the impact of the regulatory reforms on prices for 19 OECD countries over the period 1986-1996. In the long run, liberalisation and privatisation could reduce electricity prices. However, in the short run, privatisation can increase prices because governments may have an incentive to manipulate the price, in order to generate more revenues when selling the publicly 
owned assets in the electricity sector. The introduction of TPA has no significant impact on electricity prices, while the introduction of a wholesale spot market leads to lower prices. Moreover, Steiner (2001) indicates that industrial users seem to benefit more from the reforms than the residential users. Furthermore, she finds no impact from nuclear power generation on electricity prices. According to Nagayama (2007), unbundling and a wholesale pool market, when considered separately, do not reduce, but rather increase electricity prices. However, unbundling joined with an independent regulatory agency may exercise a downward pressure on prices. In some of the investigated countries, the introduction of foreign independent power producers, privatisation and retail competition did lead to lower prices. Swadley and Yücel (2011) found that increasing natural gas and coal prices positively influence end-user electricity prices. A similar conclusion regarding fossil fuel prices is also provided by Hyland (2016).

Hattori and Tsutsui (2004) use panel data to re-examine the findings presented by Steiner (2001). Expanding retail access as well as a larger share of private ownership lowers industrial prices. However, the introduction of a wholesale market resulted in higher prices. Moreover, the impact of unbundling electricity generation from transmission did not necessarily lower the price of electricity. In line with Steiner (2001), they found no evidence that nuclear generation would lead to higher prices. Hyland (2016), on the other hand, finds that that power generation from nuclear power in combination with hydropower has a negative influence on prices. However, it is inconclusive whether this drop in prices can be ascribed to the share of nuclear generation. A larger share of hydroelectric power generation had a negative impact on electricity prices in papers by Steiner (2001), Joskow (2006) and Swadley and 
Yücel (2011). Furthermore, Hattori and Tsutsui (2004) found that GDP had a negative impact on prices. It is possible that GDP captured the income effect on demand, since price data is defined as the revenue divided by the sales in $\mathrm{kWh}$. Another explanation could be that an increase in GDP is associated with an increase in electricity consumption and economies of scale, allowing the average electricity price to drop. In his papers, Nagayama (2007) found that GDP per capita has a negative impact on electricity prices in developing and developed countries. Nevertheless, he does not provide an explanation to this observation. Furthermore, the more democratic a region/country is the lower the electricity prices are. According to Joskow (2006), market reforms led to lower industrial and residential prices in the United States. Furthermore, he finds that higher interest rates are associated with higher prices. Swadley and Yücel (2011) examine the impact of retail competition programs across 16 US states. In general, end-user electricity prices tend to fall in states with high switching rates and vice versa. Moreover, price controls and a larger electricity market have a negative impact on prices. Deviations in heating and cooling degree-days have no significant impact on prices. Hyland (2016) uses data from 2001 to 2011 for 27 EU member states plus Norway in order to estimate the impact of market reforms on electricity prices for industrial consumers. She finds that separating management in transmission system operators, among others, lead to higher prices for industrial end-users. Electricity imports and the presence of a liberalised wholesale market have a negative influence on prices. However, once she accounts for the endogeneity of electricity market reforms, reforms no longer have a significant impact on electricity prices. Finally, she finds that the use of economic instruments for supporting renewables lead to higher prices for industrial end-users. 


\section{Data and regression models}

As mentioned earlier, the use of country specific variables is rather limited. Previous studies find ambiguous results regarding the impact of market reforms on electricity prices. We hypothesise that institutional variables, in particular the institutional framework of the reforms and the willingness to comply with the rules (or avoidance of corrupt activities) by economic agents other than consumers, play an important role in the success or failure of electricity market reforms in reducing electricity prices. Ample research work has been pursued linking corruption to weak economic performance in countries (Aghion et al., 2016; d'Agostino et al., 2016; Del Monte and Papagni, 2001; Drury et al., 2006; Fisman and Svensson, 2007; Mauro, 1995; Mo, 2001). Furthermore, there is also a clear relationship between corruption and regulatory quality; low quality regulation can foster corruption, but corruption can also induce the development of bad quality regulation. Complex and burdensome regulation creates greater opportunity for corrupt behaviour (Djankov et al., 2002; Holcombe and Boudreaux, 2015; Ogus, 2004), which in turn reduces the level of compliance with new and existing rules (Damania et al., 2004).

The opposite is also true. High quality regulation limits the possibility for corrupt behaviour and thus of non-compliance due to better enforcement (Breen and Gillanders, 2011). Previous research by Clarke and Xu (2002) has shown that market reforms (i.e.: introducing competition, privatisation and expanding network capacity) in the utilities sector in transitional economies, reduce the amount of corrupt behaviour. However, this success strongly depends on the institutional structure and framework behind these reforms (Damania et al., 2004; Ogus, 2004). Moreover, 
corruption leads to an inefficient use of available resources by electric utilities (Dal Bó and Rossi, 2007), which can exert additional pressure on end-user prices. The magnitude of that effect is similar to the damage done by operating in an environment characterised by low-quality regulation. Furthermore, a weak institutional framework can, among others, lead to higher electricity prices (SERV, 2013a, b). Finally, Vereeck and Vrolix (2007) have shown that the success of new regulation not only depends on its quality, but also on the willingness to comply by economic agents. Therefore, we believe that corruption and regulatory quality can influence the outcome of electricity market reforms. Reforms have little impact if the institutional design (regulatory quality) is of poor quality and the level of compliance with the rules by economic agents is low. Mutatis mutandis, reforms that have been well-implemented (regulation of high quality) and are supported by private and public agents (low levels of non-compliance) have a significant impact on prices. Therefore, we introduce institutional variables such as regulatory quality and freedom from corruption into the model. For our remaining independent variables, we made a selection from the variables presented in table 2 , taking into account the availability of the data and the models used in previous studies for investigating the impact of electricity market reforms on retail electricity prices. Wherever possible, variables have been log-transformed in order to increase the fit of the model and to help with the interpretation of the coefficients.

For our regression analysis, we will be using annual data for 22 European countries for the period 2005-2013. The data have been collected from databases of Eurostat, World Bank, OECD, IEA, CSP and the Heritage Foundation. 
The electricity price for household consumer net of tax and including taxes

(lnPexcl/lnPincl). Electricity prices will be used as the dependent variable in our models. Both variables are provided in $€ / \mathrm{MWh}^{12}$ and represent the average electricity price for the residential consumers. Taxes are defined as the total tax expenditure per MWh of electricity, and consist of excise taxes and VAT. Excise taxes are all nonVAT or VAT-equivalent components levied on electricity consumption. Previous studies mainly used prices net-of-tax. However, we believe that excise taxes and VAT should be seen as a part of regulatory reforms since the reforms are also associated with certain obligations (such as public social obligations) imposed on agents within the electricity supply, which are mainly financed through taxation on end-user electricity prices. Furthermore, we expect institutional quality and corruption to influence the level of taxation imposed on electric energy. The data for this variable is provided by the IEA.

Ownership structure (OWNER), vertical integration (VERTICAL), market structure (MSTRUC). These variables, with values ranging from 0 to 6 , incorporate different dimensions of electricity market reforms. A score of 6 indicates that there is a high market share for the largest electricity company, a dominant public ownership structure in every layer of the electricity industry and full vertical integration. A score of 0 indicates that there is less concentration, private ownership structure and no vertical integration. The data for these variables are provided by the OECD. Previous studies using this set of indicators show ambiguous results (Fiorio and Florio, 2009, 2013).

${ }^{12}$ The IEA price data had to be converted into $€ / M W h$ using the EUR/USD exchange rate provided by Eurostat. 
Share of nuclear electricity production (\%NUC). This variable represent the share of nuclear production in the total gross electricity generation including autoproduction, expressed as a percentage. This variable is computed using Eurostat time series for total gross electricity production and the gross electricity production from nuclear sources. A similar variable has been used by Steiner (2001), Hattori and Tsutsui (2004), Joskow (2006), Nagayama (2007) and Swadley and Yücel (2011) We expect this variable to have a negative influence on household electricity prices.

GDP per capita $(\ln G D P C A P)^{13}$. This variable is used as a proxy for economic activity, which is likely to influence electricity consumption. The data are provided by Eurostat. As also found by Fiorio and Florio (2009), Sen and Jamasb (2012) Fiorio and Florio (2013) and Hyland (2016), we expect a positive effect on household electricity prices.

Residential electricity consumption (InRESCO). The data are provided by Eurostat and includes the total electricity consumption by residential consumers, expressed in GWh. In line with findings by Fiorio and Florio (2009, 2013), we expect residential consumption to have a negative impact on prices since the average price of electricity should fall with increased consumption.

Freedom from corruption ( $\operatorname{lnCORR}$ ). This variable measures the level of corruption on a scale of 0 to 100 , where a score of 100 indicates that there is no corruption and a score 0 indicates a very high level corruption. The data are provided by the Heritage

${ }^{13}$ Converted to real GDP per capita using the EU28 Purchasing Power Standards (PPS). 
Foundation. This variable will be used to measure the level of compliance with the rules by economic agents. We expect corruption to have a positive impact on household electricity prices.

Regulatory quality $(R E G Q)$. This variable captures perceptions of the ability of the government to implement good policies that permit and promote private sector development. The variable is provided by the World Bank and is computed using multiple indicators from a variety of sources ${ }^{14}$ and can take a value between $-2,5$ and 2,5 with a higher value indicating a better level of regulatory quality. Different regulations can have opposing effects on electricity prices. However, we believe that once the regulation is in place, improving regulatory quality can reduce prices compared to the status quo.

Our static fixed effects model can thus be written as:

$\ln P_{i t}=\beta_{1} O_{\text {WNER }}+\beta_{2}$ VERTICAL $_{i t}+\beta_{3} M S T R U C_{i t}+\beta_{4} \% N U C_{i t}+\beta_{5} \ln G D P C A P_{i t}+$ $\beta_{6} \ln R E S C O_{i t}+\beta_{7} \ln C O R R_{i t} / R E G Q_{i t}+\delta_{t}+\xi_{i}+u_{i t}$

where $\mathrm{P}_{\text {it }}$ indicates the electricity prices for residential users (including and excluding taxes) in country $i$ and year $t$. In our model, subscript $i$ represents the unit of observation $(i=1, \ldots, 22)$ and $t$ represents the time period $(t=2005, \ldots, 2013)$. Furthermore, $\mathrm{u}_{\mathrm{it}}$ is the error term and $\xi_{\mathrm{i}}$ is used to denote the unknown intercept for each country (i.e. the country fixed effects). The latter allows us to control for time-

\footnotetext{
${ }^{14}$ More information on the composition of the indicator can be found on
} http://info.worldbank.org/governance/wgi/rq.pdf 
invariant and country-specific effects since our explanatory variables do not capture all relevant characteristics of the countries in our dataset. If they did, an ordinary least squares (OLS) regression would produce consistent and efficient parameter estimates. Time fixed effects $\left(\delta_{t}\right)$ are included to capture any variation in the outcome that can be attributed to the common trends, including macro-economic effects, across the European countries included in this dataset. Prices and some of the control variables are log transformed to increase the fit of our regression model and help facilitate the interpretation of the obtained coefficients. The potential endogeneity of the reform process is likely to have important implications on our estimates. That is, market reforms affect electricity prices, but electricity prices may also affect market reforms; higher prices might stimulate policy makers to pursue some kind of market reforms, believing that these reforms will reduce prices. The issue of endogeneity in this context was mentioned by several authors such as Nagayama (2009), Swadley and Yücel (2011) and Hyland (2016). Not taking account of endogeneity would produce biased and inconsistent estimates, which may lead to wrong policy conclusions. We assume market reforms to be exogenous in our static model. However, for the dynamic model they will be considered endogenous. It has been argued by Nerlove (2000) that all models of economic behaviour are dynamic, whereby the current behaviour is almost always dependent on the state of the system describing it. Neglecting the effect of path-dependency can lead to distorted estimates of all variables as was also shown by Gutiérrez (2003). Therefore, we introduce a lagged version of our depended variable on the right side of the equation. We hypothesize that electricity prices for residential users are affected by their previous levels i.e. the presence of a certain path-dependency. This will also 
allow us to proxy time-varying but country-specific omitted variables that can affect residential prices historically. Our new model can be presented as follows:

$\ln P_{i t}=\alpha \ln P_{i, t-1}+\beta_{1} O_{W N E R_{i t}}+\beta_{2} V_{E R T I C A L} i t+\beta_{3} M S T R U C_{i t}+\beta_{4} \% N U C_{i t}+$ $\beta_{5} \ln G D P C A P_{i t}+\beta_{6} \ln R E S C O_{i t}+\beta_{7} \ln C O R R_{i t} / R E G Q_{i t}+\delta_{t}+\xi_{i}+u_{i t}(2)$

However, introducing a lagged version of the dependant variable as a regressor in our static models will result in inconsistent estimates due to the correlation between the lagged dependent variable and the error term, $\mathrm{u}_{\mathrm{i} t}$. As mentioned by Achen (2000), the lagged dependent variable will not only pick up the effects of the excluded variables but also of the already included regressors, possibly reversing their impact or reducing it, sometimes to insignificance. We circumvent this problem by estimating our models the Blundell-Bond System Generalised Method of Moments $(\mathrm{GMM})^{15}$ estimator. We also apply the Arellano and Bond autocorrelation (AR) test in order to detect the validity of some of our instruments due to autocorrelation. As mentioned by Roodman (2009), one particular problem that can easily arise in the application of system GMM is instrument proliferation. Using the Blundell-Blond System GMM estimator on data with long time dimensions can lead to overfitting of the endogenous variables, due to the rapid growth of the number of instruments. Roodman (2009) suggests two possible techniques to address this problem. The first is to use only certain lags instead of all available lags, the default option when using the Blundell-Bond System GMM estimator. The second approach is to collapse the instrument matrix horizontally. We apply both techniques in our models.

\footnotetext{
${ }^{15}$ Our models are estimated using the two-step procedure, with Windmeijer corrected robust
} standard errors. 
Furthermore, we limit our set of instruments of our dependent variable to three lags, starting at t-2 for models with REGQ and lnCORR. For our endogenous reform variables, we only use one lag starting at $\mathrm{t}-2$. All our models pass the identification test of zero second-order autocorrelation.

\section{Results}

The results of our static two-way fixed effects model, explaining the impact of corruption and regulatory quality in the context of market reforms, are shown in table 3. The table contains two different models for prices including and excluding taxes.

Table 3 Fixed-effects estimation

Table 3 here

None of our regulatory reform variables in our models have a statistically significant impact on electricity prices. Furthermore, both the quality of regulation and the level of corruption have no significant impact on electricity prices.

The results of our dynamic models for prices including taxes are presented in table 4 . The highly significant coefficient for the lagged dependent variable confirms our assumption that running a static model over a dynamic specification would result in biased estimates. The ownership structure has no statistically significant impact on prices in our models, contrary to the findings by Fiorio and Florio (2013). Higher levels of vertical integration are associated with $8,2 \%$ to $11,7 \%$ statistically significant lower electricity prices. Higher market concentration has a statistically 
significant negative impact on electricity prices in the range of $4,5 \%$ to $4,8 \%$.

Furthermore, GDP per capita has a positive impact on electricity prices in model (4).

Both the quality of regulation and corruption are negatively associated with

electricity prices. Increasing the quality of regulation by one point leads to a decline in electricity prices between $12,4 \%$ and $12,7 \%$. Reducing corruption by $1 \%$ reduces electricity prices by up to $0,22 \%$. If an average household uses $3500 \mathrm{kWh}$ per year, a $10 \%$ reduction in corruption would reduce the annual electricity bill for this type of consumer by around $€ 12,34^{16}$.

Table 4 GMM estimation for electricity prices including taxes

\section{Table 4 here}

The results of our dynamic models for prices excluding taxes are presented in table 5. Once we use electricity prices net of tax, only vertical integration and corruption remain to have a significant impact on electricity prices. A high level of vertical integration leads to a price decline between $11,8 \%$ and $15,2 \%$, which is slightly higher than in our previous models. Our results indicate that a vertically integrated electricity industry can be beneficial for residential users in terms of lower prices. Vertical integration can help electricity companies to limit or greatly reduce their transaction costs and operate more efficiently through better coordination of operations, coordination of investments and risk management. However, the question is whether the total benefits stemming from vertical disintegration outweigh the total costs as influencing prices is only one of the goals of market reforms. Models (1), (2) and (3) in table 4 demonstrate that regulatory quality affects prices including taxes

${ }^{16}$ This value has been computed using a mean panel price of $€ 0,1602 \mathrm{kWh}$. 
but not net of taxes. We conjecture that regulatory quality has no significant impact on the economic fundamentals underlying prices net of taxes (such as wholesale, retail operation and networks costs). The tax component is particularly susceptible for regulatory quality since a tax system build on unclear tax rules induces market agents to avoid taxes through existing loopholes in the tax legislation or through corruption. Furthermore, complex and inefficient tax regulation can allow some actors to negotiate tax rulings, further reducing the tax base and government revenues, which shifts the burden to other taxpayers. In models (4) to (6) in table 4 and (5) and (6) in table 5, reducing corruption is associated with lower prices, both net of taxes and including taxes. This finding can be attributed to the specific characteristic of electricity market reforms (Boehm, 2007), which have put in place a new institutional environment, characterised by unclear rules, conflicting interests between regulators and other government agencies and a lack of experience from policymakers. This setting creates a risk for corruption, regulatory capture or regulatory opportunism. ${ }^{17}$ These results suggest that the influence of market reforms on electricity prices not only depends on the selected mix of instruments as observed in the current literature, but also on the quality of institutional design as well as the willingness to comply with the new rules. It follows that the intensity of the reforms (strict or mild) has limited impact on electricity prices when these reforms are introduced in an institutional environment characterised by high levels of corruption and low quality regulation.

Table 5 GMM estimation for electricity prices net of taxes

\footnotetext{
${ }^{17}$ There is a correlation between corruption and regulatory capture. However, regulatory capture does not automatically imply the presence of corruption.
} 


\section{Conclusions}

The objectives of the European electricity market reforms were the introduction of a competitive internal market, with free choice for consumers so they can benefit from lower prices, efficient services, environmentally friendly energy production and greater security of supply.

Our paper provides a review of existing literature related to regulatory reforms of electricity markets and its impact on end-user electricity prices.

Furthermore, we contribute to the empirical literature by assessing the impact of regulatory quality and corruption, on residential electricity prices in the context of market reforms using data for 22 European countries for the period 2005-2013.

Overall, we conclude that previous studies find ambiguous results regarding the impact of market reforms on electricity prices. Furthermore, during our review, we found that the use of institutional variables is rather limited even though these factors can play an important role in the success of potential reforms.

Using a dynamic framework, we find a clear impact of corruption and regulatory quality on residential electricity prices. Improving regulatory quality and reducing corruption, both lead to lower residential prices. Even though, we fail to find an ownership effect, we do find that vertical integration and concentration lower enduser prices. Moreover, our results support the notion that the path-dependency of 
electricity prices should be taken into account when performing these kind of analyses. Neglecting the effect of path-dependency can lead to biased estimates.

Based on our literature review and our own regression models we feel confident to make the following policy recommendations:

There is growing evidence that market reforms can lead to benefits, among which transparent and fair (i.e. cost based) electricity prices, if policy makers will support the regulatory and institutional changes needed to make these reforms work, with limited interference from political forces. There is a need for a qualified, extensive and persistent dynamic regulatory framework that is able to follow and react promptly to the negative consequences of player strategies in order to create an adequately competitive and contestable electricity market for enhancing efficiency and transferring gains to consumers. The regulatory framework must be capable of anticipating economic effects caused by market reforms and taking corrective measures when needed. Monitoring the quality of regulation should be a permanent feature in order to keep the regulatory burden at a minimum, avoiding unnecessary negative price impacts. Furthermore, improving regulatory quality as well as increasing the transparency and accountability in regulatory decision-making processes can reduce rent seeking behaviour by private and public agents via legal and corruptive activities.

Moreover, the success or failure of electricity market reforms should not only be analysed, among others, in terms of financial gains or losses for end-users and the availability of better services and choice possibilities but also by their spill-over 
effects. They include, among others, less investments and lower energy saving incentives due to lower electricity prices or limited accessibility to electricity for poor segments of electricity users in case of rising electricity prices. The introduction of new technologies and a stronger linkage between the retail and the wholesale market can offer greater pricing transparency and would allow end-users to adapt their economic decisions in line with supply and demand fundamentals. Furthermore, monitoring and regulation of prices should be a permanent feature of reforms in order to prevent the adverse impacts of these reforms on the standard of living of low-income consumers.

Finally, in order to limit the risk of abuse of market power and future collusions by electricity companies, there is a strong need in further developing the internal European electricity market through investments in interconnection. A better implementation of the internal European electricity market can ensure an open and competitive industry. Continuous investments in electricity infrastructure are essential to adapt to the consequences of economic growth in developing countries. Furthermore, the introduction of market reforms requires a careful approach, taking into account the economic and institutional development and various political factors existing in each country. Ignoring these factors can reverse some of the positive impacts resulting from there reforms. Besides, once introduced most of these policies are difficult to reverse.

Further research should place more emphasis on investigating other institutional variables and the magnitude of their impact on electricity markets. We find that there is a clear link between corruption and regulatory quality and end-user electricity 
prices in the context of market reforms. However, we do not find which approach would work of would not work in order to reduce corruptive activities and improve regulatory quality since this was not the objective of this study. Further research could address this issue by using time series analysis in order to compare the effect of using different approaches in different countries or even within one country. The resulting findings can be used to provide usable best practices on how to successfully address the issue of regulatory quality and corruption in order to improve the implementation of reforms in the electricity and other public utilities sectors. 


\section{References}

Achen, C.H., 2000. Why lagged dependent variables can suppress the explanatory power of other independent variables. Ann Arbor 1001, 48106-41248.

Aghion, P., Akcigit, U., Cage, J., Kerr, W.R., 2016. Taxation, corruption, and growth. European Economic Review 86, 24-51.

Akkemik, K.A., Oğuz, F., 2011. Regulation, efficiency and equilibrium: A general equilibrium analysis of liberalization in the Turkish electricity market. Energy 36, 3282-3292.

Bakos, G., 2001. Privatizing and liberalizing electricity, the case of Hungary. Energy Policy 29, 1119-1132.

Batalla-Bejerano, J., Costa-Campi, M.T., Trujillo-Baute, E., 2016. Collateral effects of liberalisation: Metering, losses, load profiles and cost settlement in Spain's electricity system. Energy Policy 94, 421-431.

Bode, S., 2006. On the impact of renewable energy support schemes on power prices. HWWI Research Paper 4.

Boehm, F., 2007. Regulatory capture revisited-lessons from economics of corruption. Internet Centre for Corruption Research (ICGG) Working Paper 22.

Bower, J., Bunn, D.W., Wattendrup, C., 2001. A model-based analysis of strategic consolidation in the German electricity industry. Energy Policy 29, 987-1005.

Branston, J.R., 2000. A counterfactual price analysis of British electricity privatisation. Utilities Policy 9, 31-46.

Breen, M., Gillanders, R., 2011. Corruption, institutions and regulation. Working Paper Series, UCD Centre for Economic Research.

Chester, L., Morris, A., 2012. A new form of energy poverty is the hallmark of liberalised energy sectors. Australian Journal of Social Issues 46, 435-459.

Clarke, G.R., Xu, L.C., 2002. Ownership, competition, and corruption: bribe takers versus bribe payers.

Costa-Campi, M.T., Trujillo-Baute, E., 2015. Retail price effects of feed-in tariff regulation. Energy Economics 51, 157-165.

d'Agostino, G., Dunne, J.P., Pieroni, L., 2016. Government spending, corruption and economic growth. World Development 84, 190-205.

Dal Bó, E., Rossi, M.A., 2007. Corruption and inefficiency: Theory and evidence from electric utilities. Journal of Public Economics 91, 939-962.

Damania, R., Fredriksson, P.G., Mani, M., 2004. The persistence of corruption and regulatory compliance failures: theory and evidence. Public choice 121, 363-390.

de Miera, G.S., del Río González, P., Vizcaíno, I., 2008. Analysing the impact of renewable electricity support schemes on power prices: The case of wind electricity in Spain. Energy Policy 36, 3345-3359.

De Oliveira, R.G., Tolmasquim, M.T., 2004. Regulatory performance analysis case study: Britain's electricity industry. Energy Policy 32, 1261-1276.

Del Monte, A., Papagni, E., 2001. Public expenditure, corruption, and economic growth: the case of Italy. European journal of political economy 17, 1-16.

Djankov, S., La Porta, R., Lopez-de-Silanes, F., Shleifer, A., 2002. The regulation of entry. The quarterly Journal of economics 117, 1-37.

Domah, P., Pollitt, M.G., 2001. The restructuring and privatisation of the electricity distribution and supply businesses in England and Wales: a social cost-benefit analysis.

Fiscal Studies 22, 107-146.

Domanico, F., 2007. Concentration in the European electricity industry: The internal market as solution? Energy Policy 35, 5064-5076.

Doove, S., Gabbitas, O., Nguyen-Hong, D., Owen, J., 2001. Price Effects of Regulation: International Air Passenger Transport, Telecommunications and Electricity SupplyProductivity Commission Staff Research Paper. 
Drury, A.C., Krieckhaus, J., Lusztig, M., 2006. Corruption, democracy, and economic growth. International Political Science Review 27, 121-136.

European Commission, 1996. Directive 96/92/EC of the European Parliament and of the Council of 19 December 1996 concerning common rules for the internal market in electricity, Brussels.

European Commission, 2007. DG competition report on energy sector inquiry. SEC(2006) 1724, Brussels.

Fiorio, C.V., Florio, M., 2009. The reform of network industries, privatization and consumers' welfare: Evidence from the EU15. UNIMI-Research Papers in Economics, Business, and Statistics 1088.

Fiorio, C.V., Florio, M., 2013. Electricity prices and public ownership: Evidence from the EU15 over thirty years. Energy Economics 39, 222-232.

Fisman, R., Svensson, J., 2007. Are corruption and taxation really harmful to growth? Firm level evidence. Journal of development economics 83, 63-75.

Gutiérrez, L.H., 2003. The effect of endogenous regulation on telecommunications expansion and efficiency in Latin America. Journal of regulatory economics 23, 257-286. Hattori, T., Tsutsui, M., 2004. Economic impact of regulatory reforms in the electricity supply industry: a panel data analysis for OECD countries. Energy Policy 32, 823-832. Holcombe, R.G., Boudreaux, C.J., 2015. Regulation and corruption. Public Choice 164, 75-85. Hooks, J., Tooley, S., 2015. Electricity Pricing in New Zealand and the Australian State of Queensland: Accounting for the Impact of Sector Restructuring. Financial Accountability \& Management 31, 439-462.

Hyland, M., 2016. Restructuring European electricity markets-A panel data analysis. Utilities Policy 38, 33-42.

Joskow, P.L., 2006. Markets for power in the United States: An interim assessment. AEIBrookings Joint Center Working Paper.

Joskow, P.L., 2008. Lessons Learned from the Electricity Market Liberalization.

Massachusetts Institute of Technology, Center for Energy and Environmental Policy Research.

Karahan, H., Toptas, M., 2013. The effect of power distribution privatization on electricity prices in Turkey: Has liberalization served the purpose? Energy policy 63, 614-621.

Kury, T.J., 2013. Price effects of independent transmission system operators in the United States electricity market. Journal of Regulatory Economics 43, 147-167.

Lise, W., Hobbs, B.F., Hers, S., 2008. Market power in the European electricity market-the impacts of dry weather and additional transmission capacity. Energy Policy 36, 1331-1343. Martin, R., Vansteenkiste, I., 2001. EU telecommunications and electricity marketsHeading towards price convergence? Intereconomics 36, 131-140.

Mauro, P., 1995. Corruption and growth. The quarterly journal of economics 110, 681-712. Mo, P.H., 2001. Corruption and economic growth. Journal of comparative economics 29 , 66-79.

Moreno, B., López, A.J., García-Álvarez, M.T., 2012. The electricity prices in the European Union. The role of renewable energies and regulatory electric market reforms. Energy 48, 307-313.

Munksgaard, J., Morthorst, P.E., 2008. Wind power in the Danish liberalised power market-Policy measures, price impact and investor incentives. Energy Policy 36, 39403947.

Nagayama, H., 2007. Effects of regulatory reforms in the electricity supply industry on electricity prices in developing countries. Energy Policy 35, 3440-3462.

Nagayama, H., 2009. Electric power sector reform liberalization models and electric power prices in developing countries: An empirical analysis using international panel data. Energy Economics 31, 463-472. 
Nerlove, M., 2000. An essay on the history of panel data econometrics, Panel Data Conference in Geneva.

Ogus, A., 2004. Corruption and regulatory structures. Law \& Policy 26, 329-346.

Osorio, S., van Ackere, A., 2016. From nuclear phase-out to renewable energies in the Swiss electricity market. Energy Policy 93, 8-22.

Percebois, J., 2008. Electricity liberalization in the European Union: Balancing benefits and risks. The Energy Journal, 1-19.

Pollitt, M.G., 2012. The role of policy in energy transitions: Lessons from the energy liberalisation era. Energy Policy 50, 128-137.

Rathmann, M., 2007. Do support systems for RES-E reduce EU-ETS-driven electricity prices? Energy Policy 35, 342-349.

Roodman, D., 2009. A note on the theme of too many instruments. Oxford Bulletin of Economics and statistics 71, 135-158.

Sen, A., Jamasb, T., 2012. Diversity in unity: an empirical analysis of electricity deregulation in Indian states. The Energy Journal 33, 83-130.

SERV, 2013a. Advies over de Vlaamse Regulator van de Elektriciteits- en Gasmarkt (VREG), Brussels.

SERV, 2013b. Regulatoren achtergronddocument: Berstuurlijke randvoorwaarden voor adequate marktregulering door onafhankelijke regulatoren, Brussels.

Steiner, F., 2001. Regulation, industry structure, and performance in the electricity supply industry. Available at SSRN 223648.

Swadley, A., Yücel, M., 2011. Did residential electricity rates fall after retail competition? A dynamic panel analysis. Energy Policy 39, 7702-7711.

Unger, T., Ahlgren, E.O., 2005. Impacts of a common green certificate market on electricity and CO 2-emission markets in the Nordic countries. Energy policy 33, 2152-2163.

Vereeck, L., Vrolix, K., 2007. The social willingness to comply with the law: The effect of social attitudes on traffic fatalities. International Review of Law and Economics 27, 385-408. Woo, C.-K., Zarnikau, J., 2009. Will electricity market reform likely reduce retail rates? The Electricity Journal 22, 40-45. 
Fig 1. Number of papers per region per research method

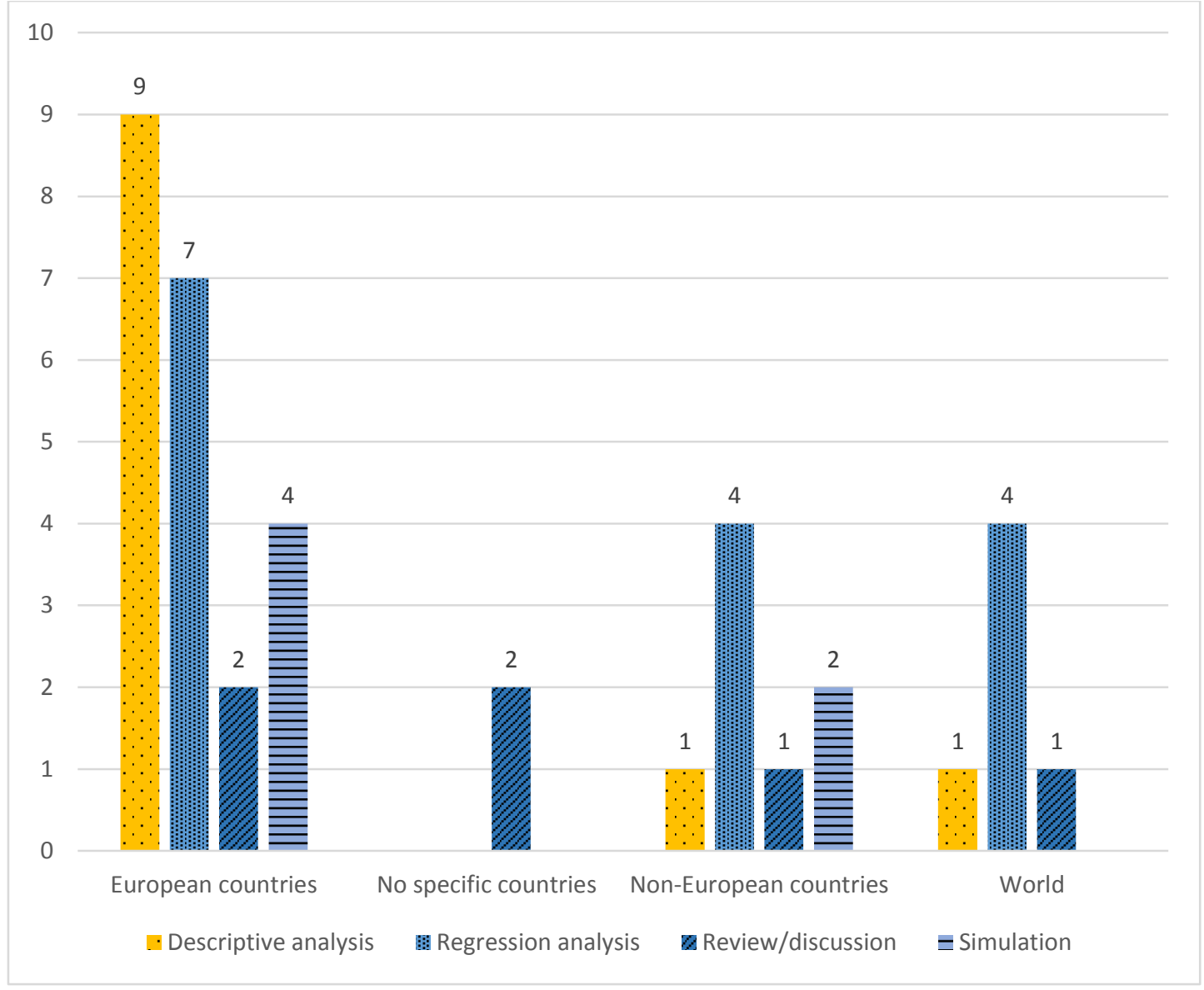


Fig 2. Papers and their variable categories

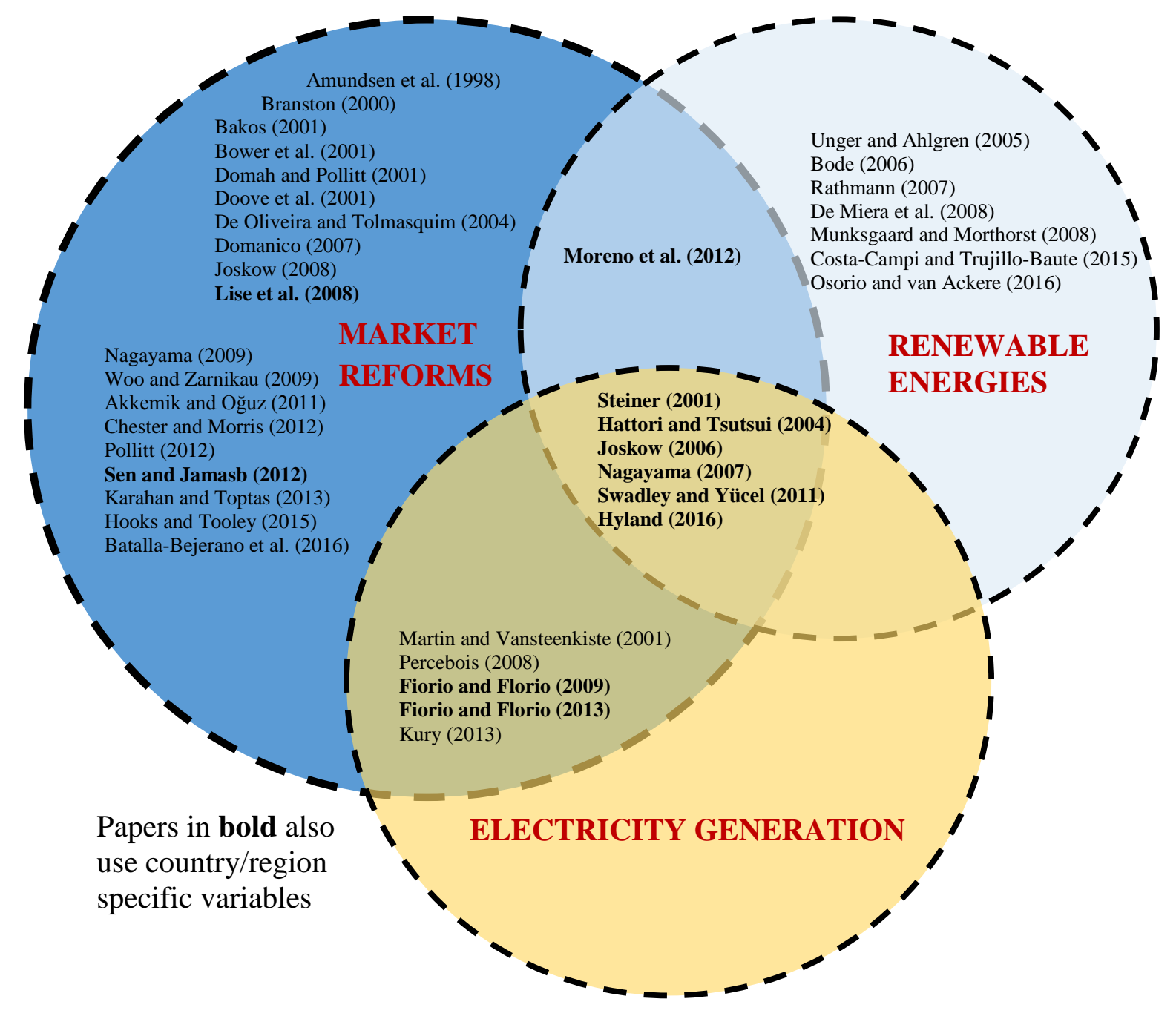


Table 1 Existing literature overview

\begin{tabular}{|c|c|c|c|c|}
\hline$\#$ & Author, date & Method & \begin{tabular}{|l|} 
Time \\
interval
\end{tabular} & Region \\
\hline 1 & Amundsen et al. (1998) & Descriptive analysis & n.a. & Norway, Sweden, Finland \\
\hline 2 & Branston (2000) & Descriptive analysis & 1988-1998 & Great Britain \\
\hline 3 & Bakos (2001) & Review/Discussion & n.a. & Hungary \\
\hline 4 & Bower et al. (2001) & Simulation & n.a. & Germany \\
\hline 5 & Domah and Pollitt (2001) & Descriptive analysis & $1985-1998$ & England and Wales \\
\hline 6 & Doove et al. (2001) & Descriptive analysis & $1986-1996$ & 50 countries \\
\hline 7 & Martin and Vansteenkiste (2001) & $\begin{array}{l}\text { Fixed effects } \\
\text { regression }\end{array}$ & $1990-2000$ & $\mathrm{EU}$ \\
\hline 8 & Steiner (2001) & $\begin{array}{l}\text { Random effects } \\
\text { regression }\end{array}$ & $1986-1996$ & 19 OECD countries \\
\hline 9 & Hattori and Tsutsui (2004) & $\begin{array}{l}\text { Fixed } \\
\text { effects/Random } \\
\text { effects regression }\end{array}$ & $1987-1999$ & 19 OECD countries \\
\hline 10 & $\begin{array}{l}\text { De Oliveira and Tolmasquim } \\
(2004)\end{array}$ & Simulation & $1989-2000$ & UK \\
\hline 11 & Unger and Ahlgren (2005) & Descriptive analysis & n.a. & $\begin{array}{l}\text { Sweden, Norway, Denmark, } \\
\text { Finland }\end{array}$ \\
\hline 12 & Bode (2006) & Descriptive analysis & n.a. & Germany \\
\hline 13 & Joskow (2006) & $\begin{array}{l}\text { Fixed effects } \\
\text { regression }\end{array}$ & $1970-2003$ & USA \\
\hline 14 & Domanico (2007) & Review/Discussion & n.a & EU \\
\hline 15 & Nagayama (2007) & $\begin{array}{l}\text { Fixed } \\
\text { effects/Random } \\
\text { effects regression }\end{array}$ & $1985-2002$ & 85 countries \\
\hline 16 & Rathmann (2007) & Descriptive analysis & $2005-2007$ & Germany, EU \\
\hline 17 & Joskow (2008) & Review/Discussion & n.a. & n.a. \\
\hline 18 & de Miera et al. (2008) & Descriptive analysis & $2005-2007$ & Spain \\
\hline 19 & Munksgaard and Morthorst (2008) & Descriptive analysis & 2001-2006 & Denmark \\
\hline 20 & Percebois (2008) & Review/Discussion & n.a. & $\begin{array}{l}\text { France, Italy, Spain, } \\
\text { Germany, Sweden, UK, } \\
\text { Belgium }\end{array}$ \\
\hline 21 & Lise et al. (2008) & Simulation & n.a. & EU-20 \\
\hline 22 & Nagayama (2009) & $\begin{array}{l}\text { Fixed } \\
\text { effects/Random } \\
\text { effects regression }\end{array}$ & $1985-2003$ & 78 countries \\
\hline 23 & Woo and Zarnikau (2009) & Review/Discussion & n.a. & Texas \\
\hline 24 & Fiorio and Florio (2009) & $\begin{array}{l}\text { Fixed effects } \\
\text { regression/GMM }\end{array}$ & $1975-2007$ & EU-15 \\
\hline 25 & Akkemik and Oğuz (2011) & Simulation & 2002 & Turkey \\
\hline 26 & Swadley and Yücel (2011) & $\begin{array}{l}\text { Fixed effects } \\
\text { regression/GMM }\end{array}$ & $1990-2010$ & $\begin{array}{l}16 \text { states (USA) + District of } \\
\text { Columbia }\end{array}$ \\
\hline 27 & Chester and Morris (2012) & Review/Discussion & n.a. & n.a. \\
\hline 28 & Sen and Jamasb (2012) & $\begin{array}{l}\text { Fixed effects } \\
\text { regression/LSDVC }\end{array}$ & $1986-2006$ & India (19 states) \\
\hline 29 & Moreno et al. (2012) & $\begin{array}{l}\text { Fixed effects } \\
\text { regression }\end{array}$ & 1998-2009 & EU-27 \\
\hline 30 & Pollitt (2012) & Review/Discussion & n.a. & n.a. \\
\hline 31 & Fiorio and Florio (2013) & $\begin{array}{l}\text { Fixed effects } \\
\text { regression/GMM }\end{array}$ & $1987-2008$ & EU-15 \\
\hline 32 & Karahan and Toptas (2013) & Simulation & $2008-2013$ & Turkey \\
\hline
\end{tabular}




\begin{tabular}{|c|c|c|c|c|}
\hline 33 & Kury (2013) & 2SLS regression & $1990-2008$ & USA \\
\hline 34 & $\begin{array}{l}\text { Costa-Campi and Trujillo-Baute } \\
\text { (2015) }\end{array}$ & Regression & $2009-2013$ & Spain \\
\hline 35 & Hooks and Tooley (2015) & Analysis & $1990-2011$ & $\begin{array}{l}\text { New Zealand and Queensland } \\
\text { (Australia) }\end{array}$ \\
\hline 36 & Batalla-Bejerano et al. (2016) & $\begin{array}{l}\text { Time series } \\
\text { regression }\end{array}$ & $2008-2010$ & Spain \\
\hline 37 & Hyland (2016) & $\begin{array}{l}\text { Fixed effects } \\
\text { regression/GMM }\end{array}$ & 2001-2011 & EU27+Norway \\
\hline 38 & Osorio and van Ackere (2016) & Simulation & n.a. & Switzerland \\
\hline
\end{tabular}


Table 2 Most used 20 variables

\begin{tabular}{|l|l|l|l|l|}
\hline Variables & Count & $\begin{array}{l}\text { Positive impact } \\
\text { on prices }\end{array}$ & $\begin{array}{l}\text { Negative impact } \\
\text { on prices }\end{array}$ & $\begin{array}{l}\text { No significant } \\
\text { impact on prices }\end{array}$ \\
\hline Hydro generation & 7 & 2 & 4 & 5 \\
GDP/capita & 6 & 5 & 1 & 4 \\
Nuclear generation & 5 & 1 & 0 & 4 \\
Wholesale market & 4 & 2 & 3 & 2 \\
Retail competition & 3 & 2 & 3 & 2 \\
Market reforms & 2 & 0 & 1 & 3 \\
Unbundling generation/transmission & 2 & 1 & 0 & 1 \\
Market power & 2 & 1 & 1 & 2 \\
Time to privatisation & 2 & 0 & 0 & 0 \\
Time to liberalisation & 2 & 2 & 0 & 2 \\
Private ownership & 2 & 1 & 1 & 2 \\
Combustible fuels generation & 2 & 2 & 0 & 2 \\
Electricity imports & 2 & 0 & 2 & 2 \\
Electricity sales & 2 & 0 & 2 & 2 \\
Entry regulation & 2 & 0 & 2 & 0 \\
GDP & 2 & 0 & 1 & 2 \\
Interconnection & 2 & 2 & 0 & 0 \\
Residential consumption & 2 & 0 & 2 \\
Public ownership & 1 & 1 & 2 \\
Fossil fuels & 2 & \\
\hline
\end{tabular}


Table 3 Fixed-effects estimation

\begin{tabular}{|c|c|c|c|c|}
\hline \multirow[b]{2}{*}{ OWNER } & \multicolumn{2}{|c|}{ Dependent variable: $\operatorname{lnPincl}$} & \multicolumn{2}{|c|}{ Dependent variable: $\ln P$ excl } \\
\hline & $\begin{array}{c}0.010 \\
(0.034)\end{array}$ & $\begin{array}{c}0.021 \\
(0.041)\end{array}$ & $\begin{array}{l}-0.013 \\
(0.024)\end{array}$ & $\begin{array}{c}0.002 \\
(0.032)\end{array}$ \\
\hline VERTICAL & $\begin{array}{l}-0.073 \\
(0.060)\end{array}$ & $\begin{array}{l}-0.069 \\
(0.062)\end{array}$ & $\begin{array}{l}-0.057 \\
(0.051)\end{array}$ & $\begin{array}{l}-0.053 \\
(0.053)\end{array}$ \\
\hline MSTRUC & $\begin{array}{l}-0.016 \\
(0.018)\end{array}$ & $\begin{array}{l}-0.014 \\
(0.018)\end{array}$ & $\begin{array}{l}-0.025 \\
(0.015)\end{array}$ & $\begin{array}{l}-0.020 \\
(0.015)\end{array}$ \\
\hline$\%$ NUC & $\begin{array}{l}-0.340 \\
(0.595)\end{array}$ & $\begin{array}{l}-0.309 \\
(0.577)\end{array}$ & $\begin{array}{c}0.610 \\
(0.804)\end{array}$ & $\begin{array}{c}0.642 \\
(0.788)\end{array}$ \\
\hline $\operatorname{lnGDPCAP}$ & $\begin{array}{c}0.170 \\
(0.262)\end{array}$ & $\begin{array}{c}0.063 \\
(0.298)\end{array}$ & $\begin{array}{c}0.231 \\
(0.182)\end{array}$ & $\begin{array}{c}0.101 \\
(0.243)\end{array}$ \\
\hline lnRESCO & $\begin{array}{l}-0.198 \\
(0.238)\end{array}$ & $\begin{array}{l}-0.201 \\
(0.235)\end{array}$ & $\begin{array}{c}0.189 \\
(0.239)\end{array}$ & $\begin{array}{c}0.216 \\
(0.229)\end{array}$ \\
\hline REGQ & $\begin{array}{c}0.008 \\
(0.111)\end{array}$ & & $\begin{array}{c}0.072 \\
(0.111)\end{array}$ & \\
\hline $\operatorname{lnCORR}$ & & $\begin{array}{c}0.149 \\
(0.262)\end{array}$ & & $\begin{array}{c}0.228 \\
(0.252)\end{array}$ \\
\hline Constant & $\begin{array}{l}-1.485 \\
(3.046)\end{array}$ & $\begin{array}{l}-1.049 \\
(3.149)\end{array}$ & $\begin{array}{c}-6.401 * * * \\
(2.155)\end{array}$ & $\begin{array}{c}-6.308 * * * \\
(2.157)\end{array}$ \\
\hline $\begin{array}{l}\text { Year fixed } \\
\text { effects }\end{array}$ & Yes & Yes & Yes & Yes \\
\hline $\begin{array}{l}\text { Country fixed } \\
\text { effects }\end{array}$ & Yes & Yes & Yes & Yes \\
\hline Observations & 182 & 182 & 182 & 182 \\
\hline $\begin{array}{l}\text { Number of } \\
\text { countries }\end{array}$ & 22 & 22 & 22 & 22 \\
\hline R-squared & 0.646 & 0.648 & 0.593 & 0.597 \\
\hline
\end{tabular}

Reported SE are heteroscedasticity-robust 
Table 4 GMM estimation for electricity prices including taxes

\begin{tabular}{|c|c|c|c|c|c|c|}
\hline & (1) & (2) & (3) & (4) & (5) & (6) \\
\hline & \multicolumn{6}{|c|}{ Dependent variable: $\operatorname{lnPincl}$} \\
\hline \multirow[t]{2}{*}{ L.InPincl } & $0.765 * * *$ & $0.791 * * *$ & $0.816 * * *$ & $0.652 * * *$ & $0.690 * * *$ & $0.689 * * *$ \\
\hline & $(0.171)$ & $(0.186)$ & $(0.118)$ & $(0.169)$ & $(0.179)$ & $(0.129)$ \\
\hline \multirow[t]{2}{*}{ OWNER } & 0.009 & 0.019 & 0.019 & 0.007 & 0.017 & 0.017 \\
\hline & $(0.022)$ & $(0.022)$ & $(0.021)$ & $(0.024)$ & $(0.024)$ & $(0.023)$ \\
\hline \multirow[t]{2}{*}{ VERTICAL } & $-0.117 *$ & -0.104 & $-0.098^{*}$ & $-0.093^{*}$ & $-0.081 *$ & $-0.082 *$ \\
\hline & $(0.063)$ & $(0.066)$ & $(0.056)$ & $(0.047)$ & $(0.045)$ & $(0.042)$ \\
\hline \multirow[t]{2}{*}{ MSTRUC } & $-0.045 * *$ & $-0.048^{*}$ & $-0.047 * *$ & $-0.047 *$ & $-0.048^{*}$ & $-0.048^{*}$ \\
\hline & $(0.021)$ & $(0.024)$ & $(0.022)$ & $(0.023)$ & $(0.026)$ & $(0.025)$ \\
\hline \multirow[t]{2}{*}{$\% \mathrm{NUC}$} & -0.013 & -0.008 & -0.012 & -0.006 & 0.009 & 0.009 \\
\hline & $(0.089)$ & $(0.089)$ & $(0.081)$ & $(0.097)$ & $(0.102)$ & $(0.088)$ \\
\hline \multirow[t]{2}{*}{ lnGDPCAP } & 0.111 & 0.105 & 0.098 & $0.180^{*}$ & 0.166 & 0.167 \\
\hline & $(0.097)$ & $(0.102)$ & $(0.095)$ & $(0.099)$ & $(0.104)$ & (0.099) \\
\hline \multirow[t]{2}{*}{ InRESCO } & 0.012 & 0.013 & 0.012 & 0.013 & 0.014 & 0.015 \\
\hline & $(0.016)$ & $(0.014)$ & $(0.012)$ & $(0.013)$ & $(0.015)$ & $(0.014)$ \\
\hline \multirow[t]{2}{*}{ REGQ } & $-0.127 *$ & $-0.127^{*}$ & $-0.124 *$ & & & \\
\hline & $(0.066)$ & $(0.071)$ & $(0.070)$ & & & \\
\hline \multirow[t]{2}{*}{ lnCORR } & & & & $-0.221 *$ & $-0.212 *$ & $-0.211 *$ \\
\hline & & & & $(0.109)$ & $(0.117)$ & $(0.116)$ \\
\hline \multirow[t]{2}{*}{ Constant } & -1.123 & -1.134 & -1.032 & -1.298 & -1.375 & $-1.400^{*}$ \\
\hline & $(1.027)$ & (1.028) & $(0.822)$ & $(0.860)$ & $(0.940)$ & $(0.809)$ \\
\hline Year effects & Yes & Yes & Yes & Yes & Yes & Yes \\
\hline Observations & 159 & 159 & 159 & 159 & 159 & 159 \\
\hline $\begin{array}{l}\text { Number of } \\
\text { countries }\end{array}$ & 22 & 22 & 22 & 22 & 22 & 22 \\
\hline sarganp & 0.507 & 0.611 & 0.698 & 0.658 & 0.738 & 0.832 \\
\hline hansenp & 0.501 & 0.519 & 0.630 & 0.489 & 0.486 & 0.622 \\
\hline $\operatorname{arlp}$ & 0.0168 & 0.0168 & 0.0239 & 0.0209 & 0.0185 & 0.0243 \\
\hline $\operatorname{ar} 2 \mathrm{p}$ & 0.154 & 0.155 & 0.159 & 0.194 & 0.178 & 0.192 \\
\hline $\begin{array}{l}\text { Number of } \\
\text { instruments }\end{array}$ & 20 & 21 & 22 & 20 & 21 & 22 \\
\hline
\end{tabular}

${ }^{*} \mathrm{p}<0.10,{ }^{* *} \mathrm{p}<0.05, * * * \mathrm{p}<0.010$

Reported SE are heteroscedasticity-robust

Models (1) and (4) include instruments for the lagged dependent variable at lag t-2, models (2) and (5) include instruments for

the lagged dependent variable at lag t-2 and t-3. Models (3) and (6) include instruments for the lagged dependent variable at lag

$\mathrm{t}-2, \mathrm{t}-3$ and $\mathrm{t}-4$ 
Table 5 GMM estimation for electricity prices net of taxes

\begin{tabular}{|c|c|c|c|c|c|c|}
\hline & (1) & (2) & (3) & (4) & (5) & (6) \\
\hline & \multicolumn{6}{|c|}{ Dependent variable: $\ln P e x c l$} \\
\hline \multirow[t]{2}{*}{ L.lnPexcl } & $0.615 * *$ & $0.590 * *$ & $0.645^{*}$ & $0.586 * *$ & $0.543 * *$ & $0.567 * *$ \\
\hline & $(0.277)$ & $(0.278)$ & $(0.322)$ & $(0.240)$ & $(0.233)$ & $(0.253)$ \\
\hline \multirow[t]{2}{*}{ OWNER } & -0.040 & -0.038 & -0.037 & -0.037 & -0.036 & -0.028 \\
\hline & $(0.034)$ & $(0.034)$ & $(0.037)$ & $(0.025)$ & $(0.027)$ & $(0.030)$ \\
\hline \multirow{2}{*}{ VERTICAL } & $-0.152 *$ & $-0.148 *$ & -0.120 & $-0.125^{* *}$ & $-0.127 * *$ & $-0.118 * *$ \\
\hline & $(0.076)$ & $(0.072)$ & $(0.084)$ & $(0.052)$ & $(0.048)$ & $(0.050)$ \\
\hline \multirow[t]{2}{*}{ MSTRC } & -0.042 & -0.048 & -0.029 & -0.046 & -0.049 & -0.030 \\
\hline & $(0.045)$ & $(0.046)$ & $(0.046)$ & $(0.037)$ & $(0.039)$ & $(0.041)$ \\
\hline \multirow[t]{2}{*}{$\% \mathrm{NUC}$} & 0.016 & 0.021 & 0.079 & 0.009 & 0.014 & -0.004 \\
\hline & $(0.233)$ & $(0.216)$ & $(0.171)$ & $(0.171)$ & $(0.174)$ & $(0.156)$ \\
\hline \multirow[t]{2}{*}{ lnGDPCAP } & 0.054 & 0.057 & 0.054 & 0.146 & 0.136 & 0.166 \\
\hline & $(0.142)$ & $(0.130)$ & $(0.100)$ & $(0.113)$ & $(0.105)$ & $(0.119)$ \\
\hline \multirow[t]{2}{*}{$\operatorname{lnRESCO}$} & -0.018 & -0.017 & -0.011 & -0.013 & -0.014 & -0.001 \\
\hline & $(0.040)$ & $(0.041)$ & $(0.027)$ & $(0.031)$ & $(0.032)$ & $(0.027)$ \\
\hline \multirow[t]{2}{*}{ REGQ } & -0.036 & -0.045 & -0.070 & & & \\
\hline & $(0.108)$ & (0.099) & $(0.101)$ & & & \\
\hline \multirow[t]{2}{*}{ lnCORR } & & & & -0.193 & $-0.184 *$ & $-0.219^{*}$ \\
\hline & & & & $(0.116)$ & (0.106) & $(0.121)$ \\
\hline \multirow[t]{2}{*}{ Constant } & -0.392 & -0.564 & -0.611 & -0.803 & -0.988 & -1.135 \\
\hline & $(1.506)$ & (1.339) & (1.140) & $(1.108)$ & (1.019) & (1.077) \\
\hline Year effects & Yes & Yes & Yes & Yes & Yes & Yes \\
\hline Observations & 159 & 159 & 159 & 159 & 159 & 159 \\
\hline $\begin{array}{l}\text { Number of } \\
\text { countries }\end{array}$ & 22 & 22 & 22 & 22 & 22 & 22 \\
\hline sarganp & 0.224 & 0.273 & 0.156 & 0.458 & 0.533 & 0.431 \\
\hline hansenp & 0.612 & 0.670 & 0.0913 & 0.702 & 0.729 & 0.275 \\
\hline $\operatorname{ar} 1 p$ & 0.0432 & 0.0564 & 0.0740 & 0.0373 & 0.0532 & 0.0664 \\
\hline $\operatorname{ar} 2 \mathrm{p}$ & 0.129 & 0.156 & 0.126 & 0.138 & 0.170 & 0.154 \\
\hline $\begin{array}{l}\text { Number of } \\
\text { instruments }\end{array}$ & 20 & 21 & 22 & 20 & 21 & 22 \\
\hline
\end{tabular}

Reported SE are heteroscedasticity-robust

Models (1) and (4) include instruments for the lagged dependent variable at lag t-2, models (2) and (5) include instruments for

the lagged dependent variable at lag t-2 and t-3. Models (3) and (6) include instruments for the lagged dependent variable at lag

$\mathrm{t}-2, \mathrm{t}-3$ and $\mathrm{t}-4$ 